\title{
Pathology attributed to Mycobacterium chelonae infection among farmed and laboratory-infected Atlantic salmon Salmo salar
}

\author{
D. W. Bruno ${ }^{1, *}$, J. Griffiths ${ }^{1}$, C. G. Mitchell ${ }^{1}$, B. P. Wood ${ }^{1}$, Z. J. Fletcher ${ }^{1}$, \\ F. A. Drobniewski ${ }^{2}$, T. S. Hastings ${ }^{1}$ \\ 'FRS Marine Laboratory, PO Box 101, Victoria Road, Aberdeen AB11 9DB, Scotland, UK \\ ${ }^{2}$ PHLS Mycobacterium Reference Unit, Dulwich Public Health Laboratory, King's College School of Medicine, \\ Dulwich Hospital, London SE22 8QF, England, UK
}

\begin{abstract}
This study was promoted following concern over increasing mortality on 2 farms rearing Atlantic salmon Salmo salar in the Shetland Isles, Scotland. A Mycobacterium sp. was isolated from moribund, market-sized Atlantic salmon. Biochemical tests, lipid analysis and PCR (polymerase chain reaction) techniques confirmed the bacterium to be Mycobacterium chelonae. Multiple greyish-white miliary granuloma-like nodules were observed in several tissues. Dense hard-packed nodules contanned abundant acid-fast bacteria. Atlantic salmon injected with $M$. chelonae remained sub-clinically infected, demonstrating the chronic nature of this disease. The source of the pathogen was not identified.
\end{abstract}

KEY WORDS: Mycobacteriosis Mycobacterium chelonae Atlantic salmon Pathology PCR

\section{INTRODUCTION}

Mycobacteria were first described from salmonids by Earp et al. (1953). The genus Mycobacterium is now recognised as being widely distributed amongst many fish groups. All fish species should therefore be considered susceptible. Outbreaks predominate, however, in tropical aquarium fish, such as the three-spot gourami Trichogaster trichopterus (Santacana et al. 1982), but also in cultured fish, including sea bass Dicentrarchus labrax (Colorni 1992), striped bass Morone saxatilis (Hedrick et al. 1987), yellowtail Seriola quinqueradiata (Kusuda et al. 1987) and farmed Pacific salmon Oncorhynchus spp. (Ashburner 1977 , Arakawa \& Fryer 1984). In European waters, mackerel Scomber scombrus have been the subject of a presumptive mycobacteriosis (Mackenzie 1988). The literature indicates that mycobacteriosis in Atlantic salmon Salmo salar is uncommon (Humphrey et al. 1987). During the late 1950 s a high prevalence within hatchery

•E-mail: brunodw@marlab.ac.uk
Pacific salmonids promoted an increase in research activity (Parisot \& Wood 1960, Ross 1963). However, when the practice of using unpasteurised fish meal in diets ceased, infection in these fish and the subsequent prevalence in returning wild fish was reduced (Parisot \& Wood 1960). Ingestion is probably a major source of infection, although ovarian transmission has been suggested as a possible route in some fish groups (Ross \& Johnson 1962, Ashburner 1977). Mycobacteriosis continues periodically to contribute to significant chronic mortality in farmed fish, principally from freshwater (Ashburner 1977), but also within the marine environment (Hedrick et al. 1987, Colorni 1992). The mycobacteria, comprising the genus Mycobacterium, are typical aerobic, Gram-positive, acid-fast staining, rodshaped bacteria. There are 3 species of Mycobacterium recognised as potential agents of fish disease, namely $M$. chelonae, $M$. fortuitum and $M$. marinum (Inglis et al. 1993, Belas et al. 1995). Typical gross pathology including emaciation, exophthalmos, keratitis and skin ulcers; and abnormal swimming behaviour has been observed (Beckwith \& Malsberger 1980, van Duijn 1981, Gómez et al. 1993). Involvement of the 
visceral organs consists of creamy-coloured, variablesized, tumour-like nodules with possible ulceration (Ashburner 1977).

This study reports on the occurrence and identification of Mycobacterium chelonae from farmed Atlantic salmon in Scotland during December 1996. The disease was identified at 2 marine fish farms in waters of $f$ the Shetland Isles, Scotland. Gross and light microscopical lesions are described. Data on the fulfilment of Koch's postulates are presented.

\section{MATERIALS AND METHODS}

The 2 marine farms studied here were designated I and III; they operate under independent management with no fish movement between the sites and are located approximately $27 \mathrm{~km}$ apart. Both farms held fish with a common freshwater origin, and an additional stock was present on 1 farm only.

Fish from natural outbreaks. Moribund farmed Atlantic salmon Salmo salar (weight 2 to $3 \mathrm{~kg}$ ) were selected from sea cages with the help of a diver or the use of a hand net at farms I and II (Shetland Isles). The water temperature was 4 to $5^{\circ} \mathrm{C}$. The fish were sampled immediately following terminal anaesthesia with MS-222 (Sigma) or held in crushed ice and examined within $1 \mathrm{~h}$ of their removal from the cages. In total, 45 moribund fish were removed for examination between mid-November-December from farm I and 5 fish were examined in mid-December from farm II. Examination of the fish consisted of recording visual gross lesions as well as sampling tissues for bacteriology, histology and virology. No recent or ongoing anti-microbial treatment was being carried out at either farm. The freshwater origin of the 2 stocks examined at each farm was established. Thirty dead and 30 apparently healthy fish from farm I were also dissected and examined for gross lesions. Atlantic salmon from 2 sites $(n=10)$ located near to farm I were also examined for gross abnormalities.

Experimental infection. Eighty Atlantic salmon post smolts $(\sim 150 \mathrm{~g})$ were transported from the FRS Marine Laboratory's site at Aultbea, Ross-shire to the Aberdeen facility, where they were allowed to acclimatise for $3 \mathrm{wk}$. All stock held at this unit are subject to regular health monitoring and no infective agent has been identified. Each fish was anaesthetised with MS-222 and injected intraperitoneally with a single dose of $0.1 \mathrm{ml}$ containing a cell suspension of $\mathrm{OD}_{540}, 0.2$ or 0.7 Mycobacterium chelonde (MT1890; isolate from farm outbreak) in phosphate-buffered saline (PBS). Following injection, fish were placed according to dose into $1 \mathrm{~m}$ circular tanks to recover. Five fish were marked ventrally with Alcian blue (injected with $0.1 \mathrm{ml}$ PBS) and placed with each challenge group. A further 10 fish were injected with PBS and held in an identical tank. Sea water was supplied to each tank at 320 to $350 \mathrm{l} \mathrm{h}^{-1}$ at ambient temperature $\left(6\right.$ to $8^{\circ} \mathrm{C}$ ). Fish were fed a commercial diet throughout the study.

Injected fish were netted, anaesthetised (MS-222) and examined, in groups of 2 to 3 per treatment over $120 \mathrm{~d}$ at approximately 7 to $10 \mathrm{~d}$ intervals. The uninfected (cohabiting and control) fish were sampled on completion of the study. Fish were sampled for histology and bacteriology according to the protocol outlined for farmed fish. Tissues from laboratory-injected fish were not sampled for virus isolation.

Bacterial isolation. Bacterial isolation was attempted from the kidney, spleen and liver of moribund farmed Atlantic salmon. Samples were inoculated onto tryptone soya agar with $2 \%$ sodium chloride (TSA), Anacker and Ordal's agar (A\&O) (using 0.5\% tryptone, as modified by Lorenzen 1993), brain heart infusion agar (BHI), and Mueller Hinton (MH). Plates were incubated at $22^{\circ} \mathrm{C}$ (TSA, BHI, $\left.\mathrm{A} \& \mathrm{O}\right)$ and $15^{\circ} \mathrm{C}(\mathrm{MH})$, and examined on alternate days for up to $5 \mathrm{wk}$. The powdered media were purchased from Unipath (TSA $\mathrm{BHI}, \mathrm{A} \& \mathrm{O})$ or Difco $(\mathrm{MH})$ and prepared in the laboratory. Kidney tissue only was sampled from the experimentally infected fish for bacteriology. This was inoculated onto TSA and MH and similarly incubated.

Morphology and biochemical characteristics. Colony morphology was recorded and cultures were subjected to Gram and Ziehl-Neelsen staining and examined microscopically. Oxidase and catalase tests were conducted and the ability of the organism to grow at $37^{\circ} \mathrm{C}$ was tested. Four isolates (MT1890, MT1892, MT1900 and MT1901) from naturally infected fish recovered on TSA were selected for additional tests. The laboratory isolates were subjected to all biochemical tests. Each isolate was inoculated onto plates of the following media: urea agar, MacConkey agar, Simmons citrate medium, pyruvic acid egg medium and Lowenstein Jensen (LJ) medium. These plates were incubated at $15^{\circ} \mathrm{C}$ for up to $10 \mathrm{~d}$ and checked on alternate days. The tests for urease, nitrate reduction, citrate utilisation and iron uptake were validated with +ve and -ve cultures from the FRS Marine Laboratory culture collection. The reduction of nitrate to nitrite required the use of a heavy inoculum taken from each isolate on TSA and suspended in $10 \mathrm{ml}$ nitrate broth (Merck) and incubated at $15^{\circ} \mathrm{C}$ for $96 \mathrm{~h}$. Equal volumes of API test reagents (Bio Mérieux) NIT1 and NIT2 were mixed, and 7 drops of the resulting solution added to each sample. Oxidative/fermentation (O/F) medium (Bio Mérieux) was stabbed with a heavy inoculum and incubated at $15^{\circ} \mathrm{C}$ for up to 1 mo. Iron uptake by production of siderophores was examined using chrome azurol S (CAS) agar (Schwyn \& Neilands 1987). 
Light microscopy. Portions of gill, kidney, heart, liver, spleen, brain, gut and pyloric caeca were dissected from farmed and laboratory-infected fish and fixed in $10 \%$ buffered formalin. These were then processed for light microscopy by sectioning and staining with haematoxylin and eosin (H\&E), Gram and ZiehlNeelsen (methods given by Bruno \& Poppe 1996). Additional sections were stained with auramine-rhodamine (Bancroft \& Stevens 1990) and examined by fluorescence microscopy. The farmed fish were reported as infected when typical acid-fast bacilli were observed in tissue sections

Virology. Kidney tissue was tested for the presence of infectious pancreatic necrosis virus (IPNV) using CHSE (chinook salmon embryo) cells, as described by Smail et al. (1995) from individual naturally infected fish. Dilutions of kidney, spleen and heart and brain homogenate were also tested for the presence of infectious haematopoietic necrosis virus (IHNV) and viral haemorrhagic septicaemia virus (VHSV) using BF-2 (blue gill fry) and EPC (epithelioma papillosum cyprini) cells according to the protocol described in European Community Commission Decision 92/532/EEC (Official Journal of the European Communities 1992). Appropriate positive and negative controls were included.

Mortality. Mortality data were collected weekly by staff at farms I and II and collated at the FRS Marine Laboratory, Aberdeen. The information was summarised as monthly mortality from all causes between August and January inclusive.

Lipid analysis by thin layer chromatography. Two isolates, MT1890 and MT1892, from naturally infected Atlantic salmon were subjected to lipid analysis by thin layer chromatography (TLC). For TLC, isolates were subcultured onto LJ medium slopes. A heavy growth was removed, dried over phosphorus pentoxide in a vacuum desiccator and the lipids extracted using a mixture of diethyl ether:ethanol:water $(17: 17: 6 \mathrm{v} / \mathrm{v})$, as described by Collins et al. (1997). Aliquots $(10 \mu \mathrm{l})$ were spotted onto TLC plates (Whatman KG Silica Plates, $250 \mu \mathrm{m}$ thick; Kodak, USA) and separated using $\mathrm{n}$ propanol:water:ammonia $(75: 22: 3 \mathrm{v} / \mathrm{v})$. The plates were dried and the chromatogram developed by treating it with concentrated sulphuric acid.

Polymerase chain reaction. The polymerase chain reaction-restriction enzyme analysis (PCR-REA) was performed essentially as described by Telenti et al. (1993). In brief, primers were used to amplify a region of the heat shock gene, hsp65, producing a 439 base pair amplification product that was subjected to electrophoresis on a $1 \%(w / v)$ agarose gel (NuSieve; FMC Bioproducts, USA) and visualised by staining with ethidium bromide. The total reaction volume was $50 \mu \mathrm{l}$ and reaction conditions were $1 \mathrm{~min}$ at $94^{\circ} \mathrm{C}, 1 \mathrm{~min}$ at $60^{\circ} \mathrm{C}$ and $1 \mathrm{~min}$ at $72^{\circ} \mathrm{C}$, followed by an extension time of $10 \mathrm{~min}$ at $72^{\circ} \mathrm{C}$. The total number of cycles was 30 . Aliquots of PCR product $(10 \mu l)$ were added to each of 2 tubes containing $5 \mathrm{U}$ of Bst EII restriction endonuclease with buffer and sterile water or $5 \mathrm{U}$ of Hae $I I I$, buffer and water. One tube was incubated at $60^{\circ} \mathrm{C}$, and the other at $37^{\circ} \mathrm{C}$ for $90 \mathrm{~min}$. All buffers and enzymes were purchased from Boehringer Mannheim, Germany. The resulting restriction digests were subjected to electrophoresis on $4 \%(\mathrm{w} / \mathrm{v})$ agarose gels and visualised as above.

\section{RESULTS}

\section{Bacterial growth and cultural characteristics}

Pure cultures were obtained from kidney, spleen and liver of fish sampled at both farms on standard media (TSA, BHI, $\mathrm{A} \& \mathrm{O}, \mathrm{MH}$ ) within 7 d incubation at $15^{\circ} \mathrm{C}$. Confluent growth from laboratory-infected fish occurred over periods of up to 3 wk at $15^{\circ} \mathrm{C}$. Biochemical properties revealed the identity of isolates from both farmed and laboratory-infected fish to be Mycobacterium chelonae. Circular, smooth, pale-cream colonies were isolated and the bacteria stained Gram-positive and acid-alcohol fast. The cultures were composed of pleomorphic rods, which were non-motile and nonsporulating and measured $2-7 \mu \mathrm{m} \times 0.2-0.5 \mu \mathrm{m}$. Biochemical characteristics are given in Table $1 . M$. che-

Table 1 Characteristics of Mycobacterium isolates MT1890 MT1892, MT1900, and MT1901 isolated from marine reared Atlantic salmon Salmo salar, and MT1915. MT1917 and MT1918 isolated from laboratory-infected Atlantic salmon

\begin{tabular}{|ll|}
\hline Test & Result \\
\hline Colony morphology & Creamy smooth \\
Motility & circular colonies \\
Pigmentation & -ve \\
Gram stain & -ve \\
& Weak, Gram- \\
Ziehi-Neelsen stain & positive rods \\
Oxidase & $+v e$ \\
Catalase & -ve \\
Oxidative/fermentation & $+v e$ \\
Growth at 37 C & Fermentative \\
Growth on: & $-v e$ \\
MacConkey agar & \\
Pyruvic acid egg & $+v e$ \\
Lowenstein Jensen & $+v e$ \\
Nitrate reduction & $+v e$ \\
Iron uptake by production of sideo- & $-v e$ \\
phores using chrome azurol S agar & $-v e$ \\
Simmons citrate utilisation & $-v e$ \\
Urease & $+v e$ \\
&
\end{tabular}


lonae appeared golden in colour when stained with auramine-rhodamine and examined by fluorescence microscopy. A Vibrio sp. was recovered in pure culture from some fish at farm I. No bacteria were isolated from the cohabiting or control fish in the laboratory trial.

\section{Gross pathology}

Moribund farmed fish moved slowly near the water surface and appeared dark with slight abdominal distention, but no skeletal deformities were observed. Skin ulcers were noted in 2 fish (farm I). Multiple, grouped or single, greyish-white miliary granulomalike nodules ( 1 to $3 \mathrm{~mm}$ in diameter) were observed throughout the kidney. The tissue was enlarged but normal in colour (Fig. 1). Similar, but smaller $(0.1$ to $1 \mathrm{~mm}$ ), granuloma-like lesions were also seen within the spleen and liver. Splenomegaly and ascites were noted in some fish. The gills were pale and focal haemorrhaging occurred in the musculature. The prevalence of typical gross mycobacterial lesions varied between 20 and $40 \%$ in the 2 stocks and within the dead fish examined at farm I. No gross lesions were recorded in the apparently healthy fish examined or in fish examined in December at 2 farms adjacent to farm I.

During the infection experiment, 3 fish appeared lethargic and darker than their cohorts. Ascites was apparent in 2 fish from the high dose group. One fish sampled at the end of the experiment from this group had greyish-white miliary granuloma-like nodules in the anterior kidney. As with the farmed fish, there was no evidence of skeletal deformity in the laboratoryinfected fish. At necropsy, other tissues appeared normal. No gross pathological changes were seen in the control groups.

\section{Mortality}

At farm I during August, mortality from all causes was low, but rapidly increased to 1425 during November. By the end of January losses had decreased to 318 for the month, representing a total loss of $4.1 \%$ during August to January. Farm II also recorded high mortality of 2208 in November, but the mortality had declined to 106 in January.

There was no mortality during the $120 \mathrm{~d}$ laboratory trial in injected, cohabiting or control fish. Isolates of Mycobacterium chelonae were recovered on TSA from the $7 / 40$ (high dose) and $2 / 40$ (low dose) groups of laboratory-infected Atlantic salmon.

\section{Histopathology}

Fish from the natural outbreak at farm I had numerous acid-fast bacteria in large circular $(\sim 400 \mu \mathrm{m})$ densely packed nodules in the kidney, liver and spleen. These nodules comprised epithelioid cells and had no surrounding capsule or fibrin deposition or central necrosis (Fig. 2). No other cellular inflamma-

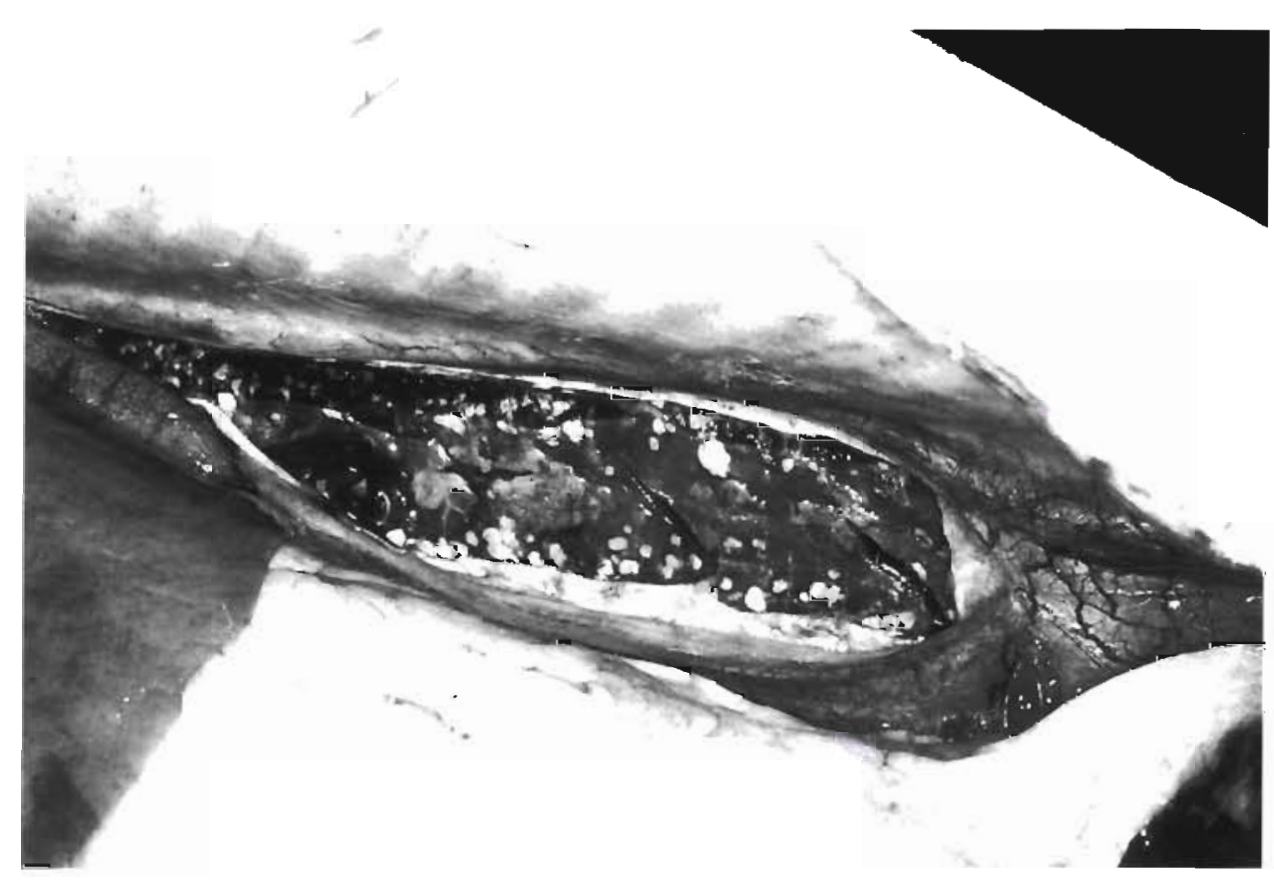

Fig. 1. Multiple, greyish-white miliary granuloma-like nodules observed in naturally infected Atlantic salmon Salmo salar 
Fig. 2. Salmo salar. Abundant Mycobacteria chelonae in large, circular, dense, hardpacked nodules in the liver from naturally infected Atlantic salmon. These nodules comprise epitheloid cells with no surrounding capsule or fibrin deposition or central necrosis. Ziehl-Neelsen stain Scale bar $=80 \mu \mathrm{m}$

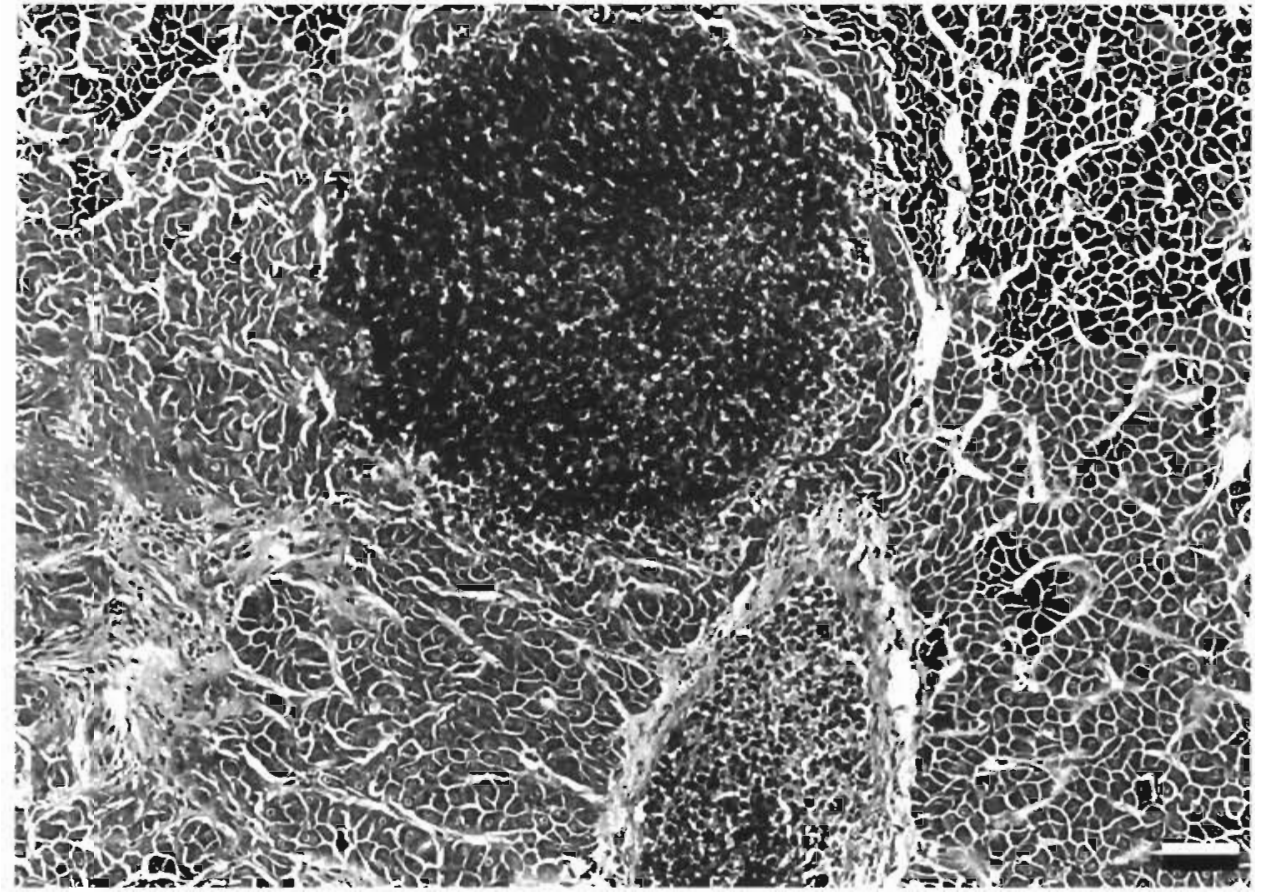

tory response to the bacteria was noted. Mycobacteria were present in large numbers within phagocytic cells in the liver and kidney (Fig. 3) with displacement of the tubules. In the liver, bacteria were present within the portal veins and there was slight degeneration of the endothelial tract. Similar lesions occurred in the spleen with concurrent congestion. Soft nodules were gener- ally associated with a graded necrosis from the bacterial focus interspersed with melanin particles, but there was no calcification. Multinucleate giant cells were not evident in any tissue. The mycobacteria stained bright red by Ziehl-Neelsen, were weakly positive using Gram staining and only a light pink using H\&E.
Fig. 3. Salmo salar. Mycobacteria chelonae proliferation in the kidney of naturally infected Atlantic salmon Ziehl-Neelsen stain. Scale bar $=20 \mu \mathrm{m}$

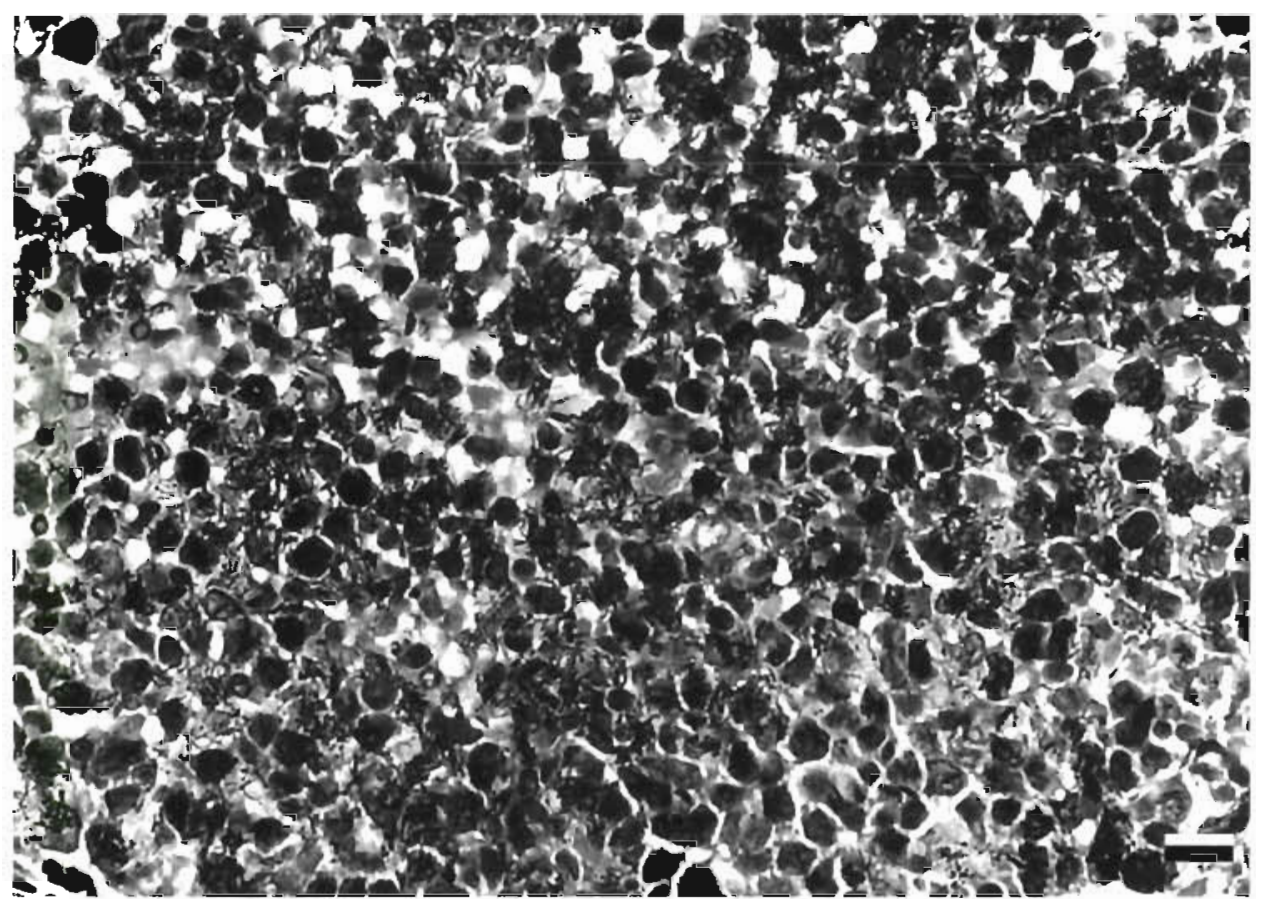




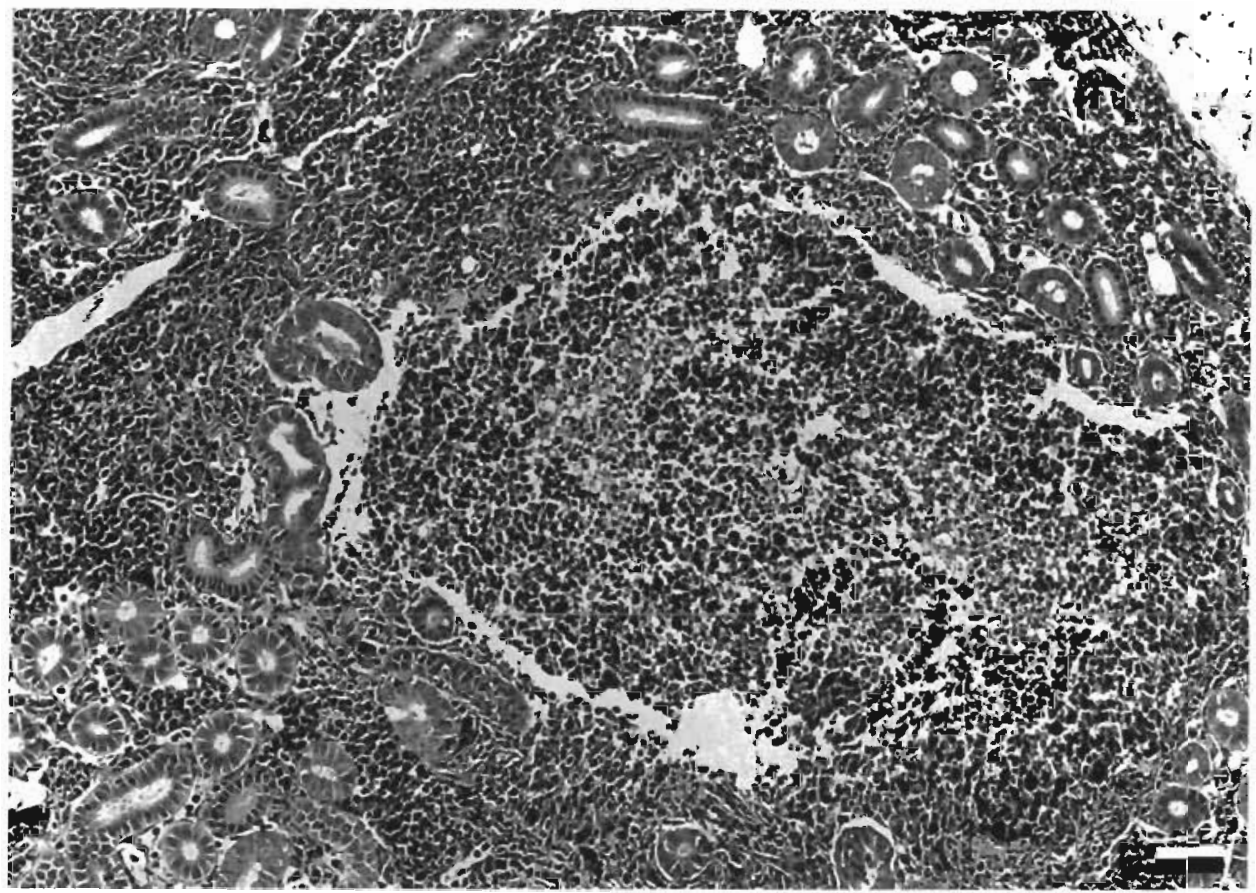

Fig. 4. Salmo salar. Mycobacteria chelonae present in kidney of naturally infected Atlantic salmon. The section shows compression of adjacent structures. Ziehl-Neelsen stain Scale bar $=100 \mu \mathrm{m}$
Subsequent tissue sampling at farms I and IJ $21 \mathrm{~d}$ later revealed fewer nodules contannng acid-fast bacteria Fish examined at farm II had many extracellular acid-fast bacteria and adjacent caseous necrosis in the kıdney with a sparse fibrotic reaction (Fig. 4) Renal elements were similarly compressed and the tubules and glomeruli destroyed. An increase in granular cells in the intestinal granulosum was noted. Throughout the laboratory study, condensed deposits of slightly darker stainıng, acld-fast debris were noted within the lining of the kidney tubules, or within the splenic pulp with localised necrosis (Fig. 5). This feature was typical of the farmed fish from farm II and similarly the laboratory-infected fish. The distinct granuloma-like

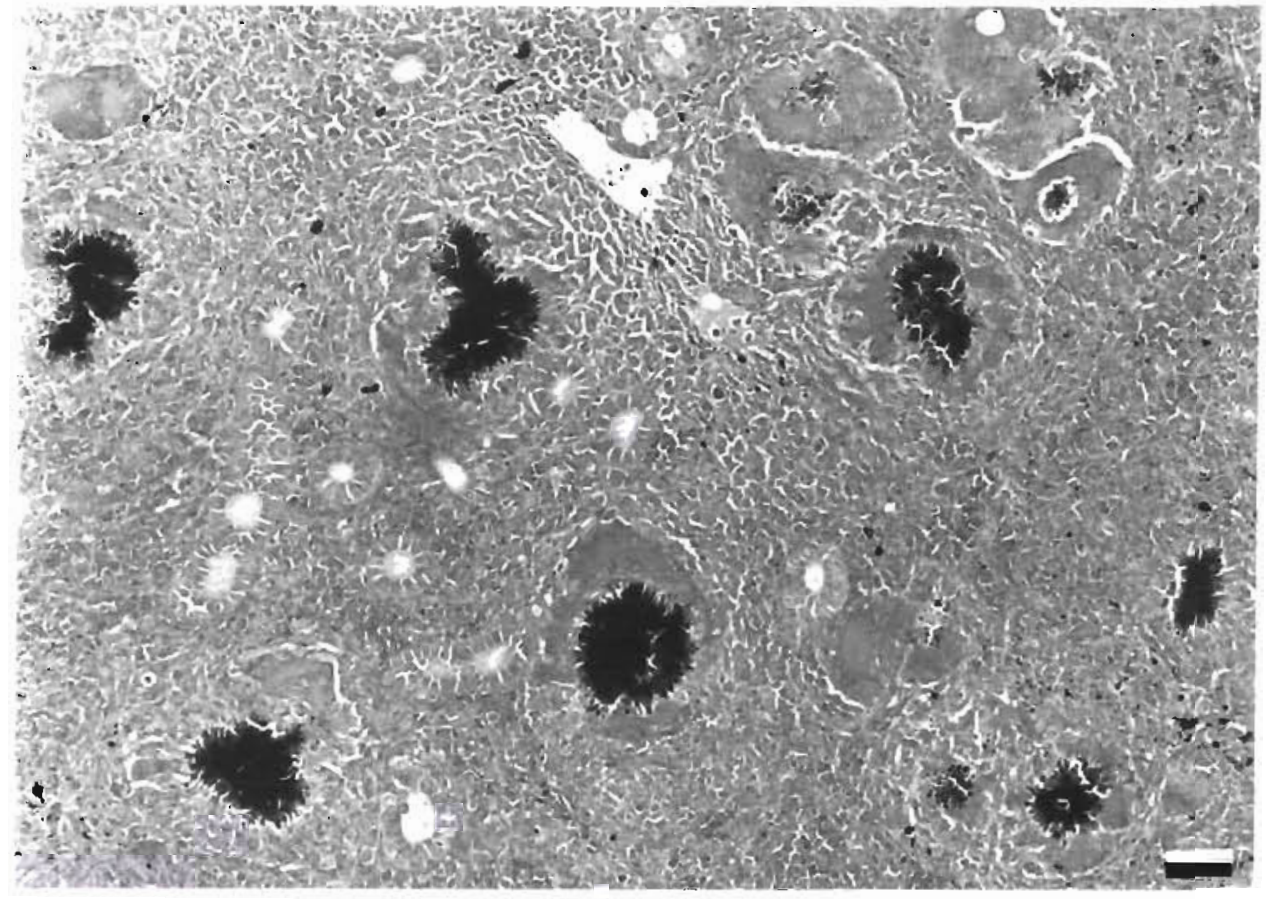

Fig. 5. Salmo salar. Condensed deposits of acid-fast debris present within the kidney tubule lumen of experimentally infected Atlantic salmon. Ziehl-Neelsen stain. Scale bar $=100 \mu \mathrm{m}$ 
nodules packed with acid-fast bacteria were only recorded in 1 laboratory-infected fish. An increase in granular cells in the intestinal granulosum was noted.

\section{Virology}

Tissue samples collected from the field were tested and found negative for IPNV, IHNV and VHSV.

\section{Lipid chromatographic profile and PCR}

Following the biochemical identification of the isolated bacteria as Mycobacterium chelonae, additional confirmatory tests were carried out. A lipid chromatographic profile and the presence of digested PCRproduct bands of 325 and 140 base pairs using the Bst EII enzyme and 210 base pairs for Hae III indicated that the cultures isolated were $M$. chelonae.

\section{DISCUSSION}

The above investigation was carried out following reports of increasing mortality among Atlantic salmon Salmo salar on 2 farms in the Shetland Isles. A Mycobacterium sp. was isolated in pure culture from fish at both sites and identified as $M$. chelonae using standard cultural and biochemical characteristics (Heifets \& Good 1994, Collins et al. 1997). The identification of $M$. chelonae was strengthened by the correlation between the biochemical properties and subsequent TLC of cell lipids and molecular DNA analysis of the hsp65 gene (Telenti et al. 1993). In some studies, identification of infections involving fish mycobacteria has not always been practical (Lund \& Abernethy 1978, Colorni 1992). However, Arakawa \& Fryer (1984) characterised nonchromogenic mycobacteria isolated from fish, which has helped with classification of this group.

The occurrence of Mycobacterium chelonae and its association with gross lesions in farmed Atlantic salmon is considered rare, with few examples evident in the literature. Furthermore, there are no apparent records of the occurrence of this bacterium in farmed salmon in the United Kingdom. Currently, mycobacterial infections are infrequent among farmed Pacific salmonids Oncorhynchus spp., although during the 1950 s infection was widespread (Parisot \& Wood 1960, Ross 1960). The withdrawal of unpasteurised fish meal from diets has reduced the prevalence of this disease. Currently, mycobacteriosis occurs predominantly in fish species cultured in warm waters, including the European sea bass Dicentrarchus labrax (Colorni 1992), striped bass Morone saxatilis (Hedrick et al.
1987) and the cichlid Oreochromis mossambicus (Noga et al. 1990).

The mortality recorded from 2 commercial farms in this study was significant, both in terms of the numbers involved and the commercial value of these affected market-sized fish. In addition to Mycobacterium chelonae, some of the mortality amongst these fish could be attributed to infection by Vibrio sp., which was isolated in pure culture from fish showing clinical signs of vibriosis. In addition to this, Aeromonas sp. had previously been recovered from 1 site. Gross examination of moribund fish allowed a provisional distinction to be made between infection by Vibrio sp. and that caused by $M$. chelonae. Subsequent culture and bacteriological analysis established that these fish were infected with a single rather than a dual infection. Gross examination of the moribund fish showed lesions consistent with mycobacteriosis in up to $40 \%$ of the fish. It was concluded that a significant proportion of the overall mortality could therefore be attributed directly to the mycobacteria. Previous reports have highlighted the significant losses that occur as a result of mycobacterial infections. In particular, the work of Hedrick et al. (1987), who attributed losses of $50 \%$ to Mycobacterium marinum in cultured striped bass, and Ashburner (1977), who reported losses of between 4 and $42 \%$ over 4 yr from infection with $M$. chelonae in chinook salmon Oncorhynchus tshawytscha in hatcheries.

Viable Mycobacterium chelonae were isolated from fish throughout the laboratory study, therefore confirming Koch's postulates, but in these laboratory experiments no mortality occurred. Gross changes typical of those noted in naturally infected fish were seen in only 1 fish over the $120 \mathrm{~d}$ experimental period. This observation confirms the chronic nature of naturally occurring fish mycobacteriosis as recognised by Ashburner (1977) and Noga et al. (1990).

Abundant acid-fast bacteria contained within large nodules in the kidney, liver and spleen were located in naturally infected fish by light microscopy. Epithelioid cells were the dominant cell type and the nodules were enclosed in a thin capsule. The absence of any other inflammatory response or giant cell formation is consistent with the observations for Mycobacterium anabanti in the three spot gourami (Santacana et al. 1982), with the case of mycobacteriosis reported in mountain whitefish Prosopium williamsoni (Lund \& Abernethy 1978) and with the infection in juvenile chinook salmon (Parisot \& Wood 1960). Mycobacteria occurred intracellularly and were scattered throughout tissues or present at the peripheral portion of lesions, as described by Lund \& Abernethy (1978). Nodules were observed and 2 distinct stages of development recorded. The compact nodules had no epithelioid sheath or central necrosis, as reported by Hedrick et 
al. (1987), and the soft nodules were generally associated with a graded necrosis from the bacterial focus. Similarly, Majeed et al. (1981) also noted the development of soft nodules in goldfish Carassius auratus. In the laboratory-infected fish, acid-fast staining debris occurred within the kidney tubule lumen. Intact bacteria were not observed in these tissues, suggesting that the bacteria were dying or were killed by the host immune response. This response was clearly limited as viable cells of $M$. chelonae were recovered on TSA throughout the experimental period.

The distance separating farms I and II is not unusual for many fish farms operating within waters around the Shetland Isles. These farms operate as independent companies with no movement of fish between the installations. The only connection in common was a freshwater stock origin. The purchase of smolts from the same supplier might suggest a freshwater origin for this outbreak, although the health status of these fish would have been regularly monitored and no prior evidence of mycobacteriosis was recorded. High infection levels in hatchery salmonids have been reported in Oregon, USA (Arakawa \& Fryer 1984) and a prevalence of $15 \%$ in some wild fish populations noted (Parisot \& Wood 1960). Furthermore, some reports of Mycobacterium chelonae infection have specifically linked outbreaks with the freshwater hatchery environment (Daoust et al. 1989, Inglis et al. 1993). This, however, would not explain the presence of $M$. chelonae-infected fish in the unrelated stock held by one farm, suggesting that horizontal transmission may have occurred in sea water. Several farmed fish from the study reported here were recorded with skin lesions and these may be areas from where bacterial shedding could occur. Further study on the source of this infection was not carried out. Interestingly, Inglis et al. (1993) reported that infection with $M$. chelonae had only been identified in cold water fish, which is consistent with the outbreak reported here.

Mycobacterium chelonae outbreaks involving farmed Atlantic salmon are rare, but in this study the organism contributed, probably directly to a significant mortality in valuable farmed stock of market size.

Acknowledgement. We thank Mr M. Yates (PHLS Mycobacterium Reference Unit) for performing the thin layer chromatography.

\section{LITERATURE CITED}

Arakawa CK, Fryer JL (1984) Isolation and characterization of a new subspecies of Mycobacterium chelonei infectious for salmonid fish. Helgoländer Wiss Meeresunters 37 $329-342$

Ashburner LD (1977) Mycobacteria in hatchery-confined chi- nook salmon (Oncorhynchus tshawytscha Walbaum) in Australia. J Fish Biol 10:523-528

Bancroft JD, Stevens A (1990) Theory and practice of histological techniques, 3rd edn. Churchill Livingstone, London

Beckwith $D G$, Malsberger RG (1980) Kidney tumour virustumour or mycobacterial tubercle? J Fish Dis 3:339-348

Belas R, Faloon P, Hannoford A (1995) Potential applications of molecular biology to the study of fish mycobacteriosis. Annu Rev Fish Dis 5:133-173

Bruno DW, Poppe TT (1996) A colour atlas of salmonid diseases. Academic Press, London

Collins CH, Grange JM, Yates MD (1997) Tuberculosis bacteriology-organisation and practice, 2 nd edn. Butterworth Heinemann, Oxford

Colorni A (1992) A systemic mycobacteriosis in the European sea bass Dicentrarchus labrax cultured in Eilat (Red Sea). Isr J Aquacult Bamidgeh 44:75-81

Daoust FY, Larson BE, Johnson GR (1989) Mycobacteriosis in yellow perch (Perca flavescens) from two lakes in Alberta. $J$ Wildl Dis 25:31-37

Earp BJ, Ellis CH, Ordal EJ (1953) Kidney disease in young salmon. Washington State Dept of Fisheries, Special report No. 1

Gómez S, Bernabé A, Gómez MA, Navarro JA, Sánchez J (1993) Fish mycobacteriosis: morphopathological and immunocytochemical aspects. J Fish Dis 16:137-141

Hedrick RP, McDowell T, Groff J (1987) Mycobacteriosis in cultured striped bass from California. J Wildl Dis 23: $391-395$

Heifets LB, Good RC (1994) Current laboratory methods for the diagnosis of tuberculosis. In: Bloom BR (ed) Tuberculosis: pathogenesis, protection and control. American Society for Microbiology, Washington, DC, p 85-110

Humphrey J, Lancaster CE, Gudkovs N, Copland JW (1987) The disease status of Australian salmonids: bacteria and bacterial diseases. J Fish Dis 10:403-410

Inglis V, Roberts RJ, Bromage NR (1993) Bacterial diseases of fish. Blackwell Science Publications, London, p 219-233

Kusuda R, Kawakami K, Kawai K (1987) A fish-pathogenic Mycobacterium sp. isolated from an epizootic of cultured yellowtail. Nippon Suisan Gakkaishi 53:1797-1804

Lorenzen E (1993) The importance of the brand of the beef extract in relation to the growth of Flexibacter psychrophilus in Anacker \& Ordals medium. Bull Eur Assoc Fish Pathol 13:64-65

Lund JE, Abernethy CS (1978) Lesions of tuberculosis in mountain whitefish (Prosopium williamsoni). J Wildl Dis $14: 222-228$

Mackenzie K (1988) Presumptive mycobacteriosis in Northeast Allantic mackerel, Scomber scombus L. J Fish Biol 32:263-275

Majeed SK, Gopinath C, Jolly DW (1981) Pathology of spontaneous tuberculosis and psuedotuberculosis in fish. J Fish Dis 4:507-512

Noga EJ, Wright JF, Pasarell L (1990) Some unusual features of mycobacteriosis in the cichlid fish Oreachromis mossambicus. J Comp Pathol 102:335-344

Official Journal of the European Communities (1.992) Commission decision 92/532/EEC. No. L 337/18-27

Parisot TJ, Wood EM (1960) A comparative study of the causative agent of a mycobacterium disease of salmonid fishes. Annu Rev Resp Dis 82:212-222

Ross AJ (1.960) Mycobacterium salmoniphilum sp. nov. from salmonid fishes. Annu Rev Resp Dis 81:241-250

Ross AJ (1963) Mycobacteria in adult salmonid fishes returning to national fish hatcheries in Washington, Oregon and 
California in 1958-59. Spec Scient Rep No. 462, U.S. Fish Wildl Serv Fisheries, Washington, DC

Ross AJ, Johnson HE (1962) Studies of transmission of mycobacterial infections in chinook salmon. Prog Fish Cult 24: $147-149$

Santacana JA, Conroy DA, Mujica ME, Marín C, De López N (1982) Acid-fast bacterial infection and its control in threespot gouramies, Trichogaster trichopterus Pallas. J Fish Dis 5:545- 547

Schwyn B, Neilands JB (1987) Universal chemical assay for the detection and determination of siderophores. Anal

Editorial responsibility: Otto Kinne,

Oldendorf/Luhe, Germany
Biochem 160:47-56

Smail DA, McFarlane L, Bruno DW, McVicar AH (1995) The pathology of an IPN-Sp sub-type (Sh) in farmed Atlantic salmon, Salmo salar L., post-smolts in the Shetland Isles, Scotland. J Fish Dis 18:631-638

Telenti A, Marchesi F, Balz M, Bally F, Bottger EC, Bodmer T (1993) Rapid identification of Mycobactena to the species level by polymerase chain reaction and restriction enzyme analysis. J Clin Microbiol 31:175-178

van Duijn C (1981) Tuberculosis in fishes. J Small Anim Pract $22: 391-411$

Submitted: February 3, 1998; Accepted: March 20, 1998 Proofs received from author(s): April 15, 1998 